\title{
Absolventi středních odborných škol a jejich prechod na trh práce ${ }^{1}$
}

\author{
JaNA TRHLÍKOVÁ
}

Abstrakt: Príspèvek se zabývá vybranými aspekty prechodu absolventù střednich odborných škol na trh práce. Zaméruje se pritom na srovnáni absolventù učebnich a maturitnich oborù střednich odborných škol v obdobi trí let od ukončeni středni školy.

Cílem príspèvku je informovat o výsledcich pruizkumu absolventů stréednich odborných škol, který byl realizován v roce 2018 na vzorku cca 1000 respondentũ v Národním ústavu pro vzdèlávání jako významná zpètná vazba o prechodu absolventů na trh práce.

Metody výzkumu: Výzkumné śetrèení je koncipováno jako longitudinálni kvantitativni dotazníkové šetrení. II. etapa, která je prédmètem tohoto článku, se zaměrila zejména na úspěšnost prechodu na trh práce a uplatnèni ve vystudovaném oboru.

Výsledky prinináseji informace o reflexi vzdělávací a profesni dráhy absolventio odborných škol, zejména umožňuji srovnáni spokojenosti a uplatněni absolventư učebnich a maturitnich oborù.

Závèry výzkumného šetrèni umožñuji identifikovat problémy, potréby a bariéry v rámci kariérové volby, slabá mista ve vzdèláni z pohledu absolventư, jejich prïpravenost pro trh práce i terciárni vzdèláváni.

Klíčová slova: absolventi strednich odborných škol, trh práce, uplatnění v oboru, prechod na trh práce.

\section{ÚvOD}

Absolventi škol patří tradičně ke skupinám, jejichž postavení na trhu práce je rizikové a výrazně závislé na celkové ekonomické situaci. To se poměrně významným způsobem projevilo $\mathrm{v}$ době ekonomické krize, kdy míra nezaměstnanosti absolventů po roce 2008 rostla rychleji než v jiných skupinách pracovníků. Uvedený vývoj zároveň odkryl výrazné rozdíly jak mezi jednotlivými kategoriemi vzdělání, tak mezi skupinami oborů z hlediska schopnosti absolventů obstát $\mathrm{v}$ nepřínivých ekonomických podmínkách. Míra nezaměstnanosti vyučených tak v době krize rostla výrazněji než v kategorii absolventů maturitních oborů (v roce

\footnotetext{
${ }^{1}$ Výsledky analýz prezentované $\mathrm{v}$ př́íspěvku jsou součástí publikace „Přechod absolventů středních škol na trh práce - II. etapa“ a chystané publikace NÚV zaměřené na porovnání vybraných skupin oborů (podzim 2019).
} 
2010 dosáhla $17,7 \%$ oproti $10,6 \%$; Úlovec \& Vojtěch, 2018), zatímco absolventi maturitních oborů byli naopak schopni si častěji najít práci mimo absolvovaný obor (Trhlíková, 2013).

V současném období rychlého ekonomického růstu, kdy se rezervy volné pracovní síly postupně vyčerpávají, se do popředí dostávají naopak problémy související s nedostatkem absolventů určitých oborů a jejich připraveností pro trh práce, tedy kvantitativním a kvalitativním nesouladem mezi vzděláváním a trhem práce. Velký podíl na těchto disproporcích má ovšem i nepříznivý demografický vývoj. Zatímco v roce 2006 vstoupilo do 1 . ročníků středních škol, včetně gymnázií, kolem 140000 žáků, v roce 2017 to bylo již jen necelých 100000 žáků (Vojtěch \& Chamoutová, 2018).

Přechod absolventů na trh práce je komplexním složitým procesem, který je předmětem zkoumání $\mathrm{v}$ zemích $\mathrm{EU}$ i v rámci ČR. $\mathrm{K}$ informačním zdrojům z této oblasti patří kromě tvrdých statistických dat, jako je např. míra nezaměstnanosti, data o oborové a vzdělanostní struktuře žáků i absolventů nebo shoda vzdělání a zaměstnání, i šetření žáků a absolventů středních škol, které periodicky realizuje Národní ústav pro vzdělávání. Problematikou absolventů vysokých škol se dále zabývá Středisko vzdělávací politiky, např. v rámci projektu REFLEX (Koucký, Ryška \& Zelenka, 2014).

Vzhledem $\mathrm{k}$ rozsahu problematiky přechodu absolventů na trh práce se článek soustředuje pouze na vybrané aspekty tohoto procesu, zejména na vztah absol- ventů $\mathrm{k}$ oboru a profesi, a to jak $\mathrm{v}$ rovině zpětné reflexe, tak i reálného uplatnění na trhu práce. Okrajově mapuje také nový fenomén paralelního průběhu studijního a pracovního života, kdy stále častěji dochází k postupnému „vplouvání do profese již během studia. Vzhledem $\mathrm{k}$ tomu, že významným prediktorem průběhu i úspěšnosti vstupu na trhu práce je úroveň vzdělání, zaměřuje se článek na srovnání dvou nejvýznamnějších kategorií vzdělání - absolventů středního vzdělání s výučním listem (kategorie $\mathrm{H}$ ) a absolventů středního vzdělání s maturitní zkouškou (kategorie M). Kompletní studie a analýzy budou dostupné na stránkách www. nuv.cz a www.infoabsolvent.cz.

\section{TEORETICKÝ RÁMEC ZKOUMÁNÍ PŘECHODU ABSOLVENTŮ}

\section{NA TRH PRÁCE}

Přechod mezi vzděláváním a profesním uplatněním představuje zásadní životní fázi. $\mathrm{Z}$ pohledu absolventů je přechod do pracovního procesu obdobím změny statusu, během něhož se mladí lidé přesouvají z celodenního vzdělávání do stabilního postavení na trhu práce. Přechod je dokončen $\mathrm{v}$ okamžiku, kdy jedinec získá stabilní zaměstnání. Z makroekonomického hlediska je období přechodu ukončeno, jakmile je míra nezaměstnanosti kohorty mladých lidí stejná jako nezaměstnanost kohorty dospělých (Descy \& Tessaring, 2005).

Výsledky analýz $\mathrm{v}$ rámci OECD ukazují, že př́echod mladých lidí z po- 
čátečního vzdělávání do pracovního života probíhá v sociálním, ekonomickém a vzdělávacím kontextu, je ovlivněn organizací trhů práce, povahou a strukturou vzdělávacích systémů, vnitřními vztahy mezi klíčovými aktéry, jako jsou zaměstnavatelé, školy a vlády. A rovněž i národní hodnoty a tradice se ukazují jako faktory, které mohou tyto národní odlišnosti podmiňovat (OECD, 2000).

Vzhledem $\mathrm{k}$ tomuto širokému kontextu může být přechod na trh práce analyzován jak z hlediska různých aspektů a souvislostí, tak v odlišné míře komplexnosti. Součástí přístupů je i sledování změn charakteru samotného přechodového procesu a jeho délky. Doba přechodu do pracovního procesu je $\mathrm{v}$ jednotlivých zemích odlišná, ovšem od 90. let OECD hovoří o delších a složitějších přechodech než v minulosti. V souvislosti s tím se prosazuje snaha vnímat přechod na trh práce jako proces, během něhož stále častěji dochází k prolínání pracovních a studijních aktivit (OECD, 2000). Trend prodlužování transformačního procesu a vzájemné ovlivňování pracovní a studijní kariéry, včetně s tím souvisejících pozitivních i negativních efektů, můžeme pozorovat i v ČR (Trhlíková, 2017).

Výzkumy $\mathrm{v}$ oblasti přechodu absolventů na trh práce se často soustředují na vymezení systémových faktorů. Cenným nástrojem zkoumání determinantů přechodového procesu je srovnávací výzkum. Ten umožňuje měrit rozdíly a podobnosti v různých zemích, porovnat procesy integrace na trhu práce, identifikovat rozhodující faktory a vytvářet typologie vazeb a přechodových vzorců. Analýza odlišných národních zkušeností rozšiřuje důkazy o klíčových otázkách, jako je nap̌r. dopad výše minimální mzdy na nezaměstnanost absolventů, vliv učňovského vzdělávání nebo otázka, zda převaha interních trhů práce zhoršuje možnosti mladých lidí získat zaměstnání (Ryan, 2001). Hannan, Raffe a Smyth (1996) došli k názoru, že nejdůležitějšími znaky, které ovlivňují charakter přechodového procesu, jsou standardizace, stratifikace a síla vazeb mezi systémem vzdělávání a trhem práce. $\mathrm{V}$ systémech $s$ vyšší mírou standardizace a silnějších vazeb mezi vzděláváním a trhem práce, tedy např. učebních osnov, se zaměstnavatelé mohou více spolehnout na certifikáty o dosažené úrovni vzdělání, což přechod absolventů na trh práce usnadňuje. Další autoři se zaměřili na vliv rozdílů $\mathrm{v}$ převažujícím charakteru pracovního trhu, kdy na tzv. profesních trzích práce (occupational labor market) jsou pracovní místa jasně definována, pokud jde o jejich obsah a jsou konzistentní $\mathrm{v}$ jednotlivých podnicích a odvětvích. Zaměstnavatelé mohou ze získané kvalifikace odvodit, jaké kompetence absolventi získali. $\mathrm{Na}$ interních trzích (internal labor market) jsou pracovníci stojící mimo podnik přijímáni jako nekvalifikovaná pracovní síla a $\mathrm{k}$ posunu na kvalifikovanější pracovní místa dochází až po určitém období profesní př́ípravy, která probíhá $\mathrm{v}$ daném podniku (Garonna \& Ryan, 1991).

Autoři Pascaline Descy a Manfred Tessaring (2002) identifikovali země, kde je vzdělávací systém těsně provázán $s$ trhem práce, kam patři vedle Němec- 
ka, Rakouska, Dánska, Mad’arska a Nizozemska i Česká republika, dále země, kde je tento vztah omezený (Austrálie, Japonsko, Kanada, USA), a země, kde se těsnost propojení mezi systémem vzdělávání a pracovním trhem liší ve vazbě na zvolenou vzdělávací dráhu (Velká Británie, Estonsko, Finsko, Francie, Řecko, Norsko, Portugalsko, Skotsko a Španělsko). V souvislosti s těsností a charakterem vazeb mezi trhem práce a vzdělávání upozorňují i na odlišné postavení a prestiž odborného vzdělávání (VET) ve srovnání se všeobecným vzděláváním a na odlišné výzvy, které před odborným vzděláváním $\mathrm{v}$ těchto zemích stojí.

$\mathrm{Na}$ druhé straně se ukazují i určité limity srovnávacích výzkumů. Rozšiřování výzkumů vede $\mathrm{k}$ tomu, že jsou postupně identifikovány další dimenze ovlivňující specifika přechodu na trh práce, jako jsou flexibilita vzdělávacího systému, systémy poradenství nebo rodinné vazby. $\mathrm{V}$ důsledku toho se stále více prosazuje multidimenzionální prŕstup (OECD, 2000). Přechodové systémy jsou pak vnímány spíše jako soubor institucionálního uspořádání, který vytváří vlastní „logiku“ nebo „vzorec“ přechodového procesu (Raffe, 2011).

Podstatnou součástí analýz přechodového procesu je sledování dosažených výsledků, jako jsou nezaměstnanost absolventů, shoda vzdělání a zaměstnání, spokojenost se vzdělávací dráhou i úrovní kompetencí, charakter pracovní smlouvy a řada dalších. Tyto aspekty lze použít jako klíčová kritéria pro posouzení efektivnosti přechodu (OECD, 2000).

\section{VZDĚLÁVACÍ DRÁHA ABSOLVENTŮ \\ Z POHLEDU ZÁKLADNÍCH}

STATISTICKÝCH ÚDAJU゚

Obecně nejsilnějším prediktorem úspěšnosti na trhu práce je dosažené vzdělání (Raffe, 2011). Zaměříme se proto nejprve na základní statistické údaje vztahující se ke vzdělávací dráze absolventů středních škol učební a maturitní úrovně vzdělání.

Specifikum středního odborného vzdělávání spočívá $\mathrm{v}$ tom, že připravuje žáky jak pro prrímý vstup na trh práce, tak i pro pokračování ve studiu. Př́prava žáků $\mathrm{v}$ učebních oborech je přitom zaměřena především na přímý vstup do praxe. Podíl žáků se zde dlouhodobě pohybuje kolem $30 \%$ populačního ročníku a zůstává stabilní (v roce 2018 29,4\%). V důsledku demografického poklesu ovšem dochází jak v učebních, tak i v maturitních oborech $\mathrm{k}$ poklesu počtů žáků. $\mathrm{Z}$ hlediska další vzdělávací dráhy mohou absolventi učebních oborů získat maturitu v nástavbovém studiu. Faktem ovšem je, že počty žáků vstupujících do nástavbového studia výrazně klesají. V roce 2018 vstoupilo do denní formy studia již jen 4857 žáků oproti přibližně 11000 v roce 2006 . Roli zřejmě hraje i zavedení státní maturitní zkoušky v roce 2011 a poměrně vysoká neúspěšnost žáků $\mathrm{v}$ rámci nástavbového studia (kolem $75 \% \mathrm{z}$ nich studium nedokončí). Přibližně $35 \% \mathrm{z}$ těch, kterým se nástavbu podaří zvládnout, pokračuje dále v terciárním vzdělání. I z nich ovšem kolem $60 \%$ studium VŠ nebo VOŠ ne- 
dokončí (Vojtěch \& Chamoutová, 2019). Přes tuto poměrně výraznou neúspěšnost je zachování průchodnosti vzdělávací soustavou nutné, protože v opačném př́padě by se absolvování učebního oboru stalo slepou vzdělávací uličkou.

$V$ případě středního odborného vzdělání zakončeného maturitní zkouškou (kategorie $\mathrm{M}$ ) se podíl žáků pohybuje kolem $40 \%$ a je rovněž poměrně stabilní. $\mathrm{V}$ současnosti má nadpoloviční většina těchto absolventů zájem pokračovat v terciárním vzdělávání. $V$ této souvislosti je ovšem třeba uvést, že významné procento žáků si vybírá stř̌ední odborné vzdělávání s maturitní zkouškou i z toho důvodu, že poskytuje odbornou kvalifikaci pro přímý vstup na trh práce, tedy bez nutnosti studovat VŠ nebo VOŠ (61 \%). Tomu odpovídá i skutečnost, že nezanedbatelné procento $(38 \%)$ po maturitě vstupuje přímo na trh práce (Vojtěch \& Kleňha, 2018).

V roce $2017 / 2018$ bylo přijato ke studiu na VŠ 54,8 \% a na VOŠ 9,8\% absolventů maturitních oborů. Tento podíl se v posledních letech př́liš nemění, ovšem vzhledem $\mathrm{k}$ demografickému poklesu dochází v absolutních počtech $\mathrm{k}$ poklesu studujících v terciárním vzdělávání (tamtéž).

\section{CÍlE, METODIKA ŠETřENÍ}

\section{A SBĚR DAT}

Metodika výzkumného šetření absolventů vychází z longitudinálního prístupu, kdy je $\mathrm{v}$ rámci této koncepce opakovaně dotazován stejný vzorek žáků a absolventů, a to ve třech časových bo- dech: v závěru studia na střední škole, po 3 letech a po 6 letech od ukončení studia na střední škole.

Výběr vzorku pro I. etapu (rok 2015), byl proveden jako stratifikovaný z hlediska kategorie vzdělání i skupin oborů. V rámci celé ČR byl proveden náhodný výběr středních škol tak, aby výsledná struktura oslovených žáků posledních ročníků přibližně kopírovala celkovou reálně existující strukturu žáků podle kategorie vzdělání a významných skupin oborů. Prostřednictvím škol bylo získáno 7836 e-mailových kontaktů na žáky, včetně souhlasu s účastí na realizaci šetření. $\mathrm{V}$ rámci II. etapy realizované $\mathrm{v}$ roce 2018 byl s odstupem 3 let od ukončení střední školy osloven totožný vzorek respondentů. Sběr dat byl realizován prostřednictvím elektronického dotazníku, přičemž bylo celkem sesbíráno 1169 dotazníků (návratnost 16,2 \%). Z hlediska kategorií vzdělání bylo ve vzorku zastoupeno 222 (19,0\%) absolventů středního vzdělání s výučním listem (kategorie H), 22 (1,9\%) absolventů středního vzdělání s výučním listem a maturitní zkouškou - kategorie L0 a $925(79,1 \%)$ absolventů středního vzdělání s maturitní zkouškou.

Cílem šetření bylo zmapovat průchod vzděláváním počínaje volbou střední školy a oboru přes hodnocení spokojenosti $s$ dosaženým vzděláním až $\mathrm{k}$ jednotlivým aspektů úspěšnosti vstupu na trh práce a do terciárního vzdělávání. Jak již bylo dříve uvedeno, $\mathrm{v}$ článku se podrobněji věnujeme jen vybraným otázkám, především vztahu absolventů $\mathrm{k}$ oboru a uplatnění v něm. 


\section{VÝSLEDKY ŠETŘENÍ}

\section{Reflexe volby střední školy a získaného vzdělání}

Nejkomplexnějším hodnocením dosaženého vzdělání na střední škole je zřejmě odpověd' na otázku, zda by absolventi zopakovali volbu svého oboru a úrovně vzdělání. Součástí zpětného posouzení volby vzdělávací cesty je proto tzv. míra identifikace s oborem udávající podíl absolventů, kteří by si v prrípadě, že by mohli svoji studijní volbu zopakovat, vybrali stejný obor studia.

Z výsledků analýz (obr. 1) vyplývá, že při hypotetické možnosti zopakovat volbu oboru by si stejný obor zvolilo 73,6\% absolventů středního vzdělání s maturitní zkouškou, zatímco v kategorii absolventů učebních oborů jen $60,6 \%$ z nich.

Míra identifikace se $\mathrm{v}$ jednotlivých skupinách oborů výrazně liší. V kategorii vyučených by si znovu stejný obor zvolili nejčastěji absolventi strojírenských a elektrotechnických oborů $(64,3 \%$ a $76,2 \%)$, naopak nejméně často by svoji volbu zopakovali absolventi ve skupině Osobní a provozní služby $(40,9 \%)$. V kategorii maturitních oborů by, podobně jako u vyučených, stejný obor znovu zvolili nejčastěji absolventi strojírenských (85,3\%) a elektrotechnických (84,2\%) oborů a dále absolventi ve skupině Právo, právní a veřejnosprávní činnost $(80,0 \%)$.

Důvody, proč by si absolventi zvolili raději jiný obor studia, tvoří poměrně širokou škálu. Odlišnosti najdeme jak ve vztahu ke kategorii vzdělání (obr. 2), tak i v rámci skupin oborů. Dominantním důvodem v obou kategoriích je ztráta zájmu o vystudovaný obor $(61,3 \%$ z vyučených a $60,3 \%$ $\mathrm{z}$ absolventů maturitních oborů, kteří by si vybrali raději jiný obor). Podstatným zjištěním je skutečnost, že v kategorii vyučených jsou jako důvod volby jiného oboru častěji zmiňovány nevyhovující podmínky na trhu práce, zejména nízké platové ohodnocení

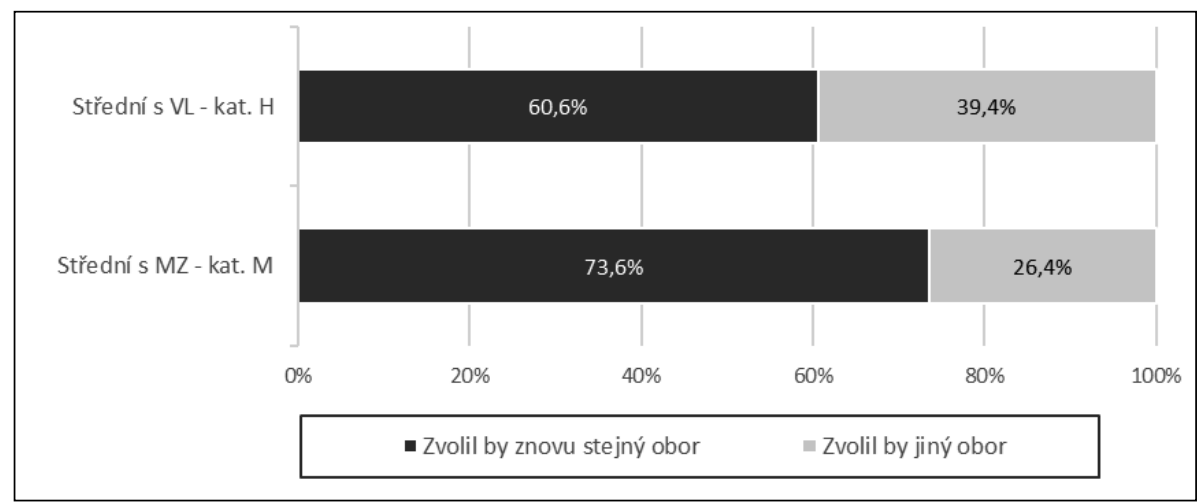

Obr. 1. Míra identifikace s oborem (v \% odpovědí) 
oboru $(50,0 \%$ oproti $43,1 \%$ z těch, kteří by zvolili jiný obor) a špatné pracovní podmínky (48,4\% oproti $23,4 \%)$. Ukazuje se tak, že nižší spokojenost vyučených $s$ volbou oboru výrazněji souvisí s pracovním uplatněním a podmínkami poskytovanými zaměstnavateli. Rovněž problémy se získáním zaměstnání v oboru jsou mírně častěǰsí u vyučených $(38,7 \%$ oproti $35,4 \%)$. Absolventi učebních oborů také častěji uvádějí, že obor původně vůbec studovat nechtěli $(43,5 \%$ a 38,8\%). Toto zjištění souvisí s tím, že řada vyučených si volí obor jako náhradní řešení. Více než třetina $\mathrm{z}$ těch, kteří by si vybrali jiný obor, v obou sledovaných kategoriích považuje svůj obor za neperspektivní. Vysoká nespokojenost $s$ oborem odráží i případné rozčarování a nespokojenost s nízkou úrovní př́pravy $(37,1 \%, 36,8 \%)$. Naopak př́liš vysoké studijní nároky jsou $\mathrm{v}$ obou kategoriích relativně málo častým důvodem nespokojenosti s oborem (19,4\%, 15,3\%).

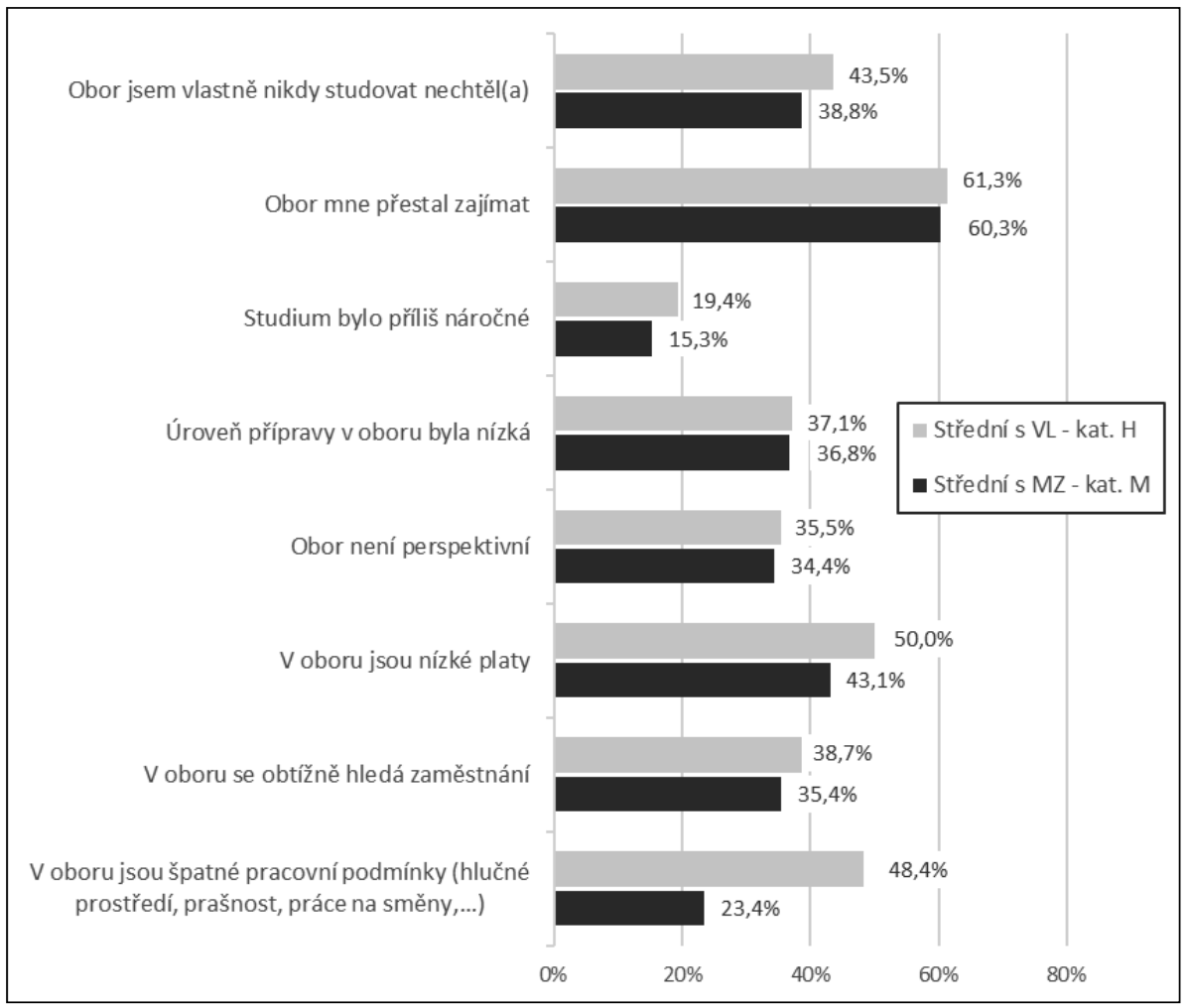

Obr. 2. Důvody odlišné volby oboru při hypotetické možnosti volbu opakovat (tři roky od ukončení střední školy, možnost výběru více odpovědí současně, v \% odpovědí rozhodně ano + spíše ano) 
Kromě spokojenosti s oborem se šetření zaměřilo i na otázku, zda by si absolventi zvolili znovu stejnou kategorii, resp. úroveň vzdělání. Zatímco absolventi maturitních oborů by $\mathrm{v}$ naprosté většině znovu zvolili maturitní úroveň vzdělání, ve skupině vyučených se podíl těch, kteři by se znovu vyučili, pohyboval kolem $74,4 \%$. Přibližně čtvrtina vyučených by tedy dala přednost maturitnímu vzdělání. I když se jedná o hypotetickou volbu, tento výsledek potvrzuje celkově nižší spokojenost vyučených se zvolenou vzdělávací dráhou, a to jak vzhledem $\mathrm{k}$ oboru, tak vzhledem $\mathrm{k}$ úrovni vzdělání.

\section{Zahájení pracovní dráhy absolventů středních škol}

Výsledky výzkumů realizovaných v zemích EU ukazují na nový trend, kdy se přechod na trh práce stává postupným a dlouhodobým procesem. Kombinace vzdělávání a zaměstnání má různé formy, zahrnuje jak učňovství (duální systém), tak i studenty pracující na částečný úvazek a rovněž zaměstnance, kteří dále studují. Mladí lidé tak při přechodu na trh práce setrvávají po určitou dobu $\mathrm{v}$ tzv. dvojím statusu, který zahrnuje jak „pracující studenty“, tak i „studující pracovníky“ (Raffe, 2011).

Podobný trend lze sledovat i v ČR. $\mathrm{V}$ rámci vzorku absolventů středních škol v období 3 let od ukončení střední školy zahájilo pracovní dráhu - ve smyslu získání dlouhodobého pracovního místa na pracovní smlouvu, DPČ nebo jako OSVČ - 69,2\% vyučených, z nichž 12,3\% kombinovalo dlouhodobou práci se studiem. Naopak 30,8\% dlouhodobou pracovní činnost nezahájilo (obr. 3). Ve skupině maturitních oborů začalo dlouhodobě pracovat 75,5\% dotázaných,

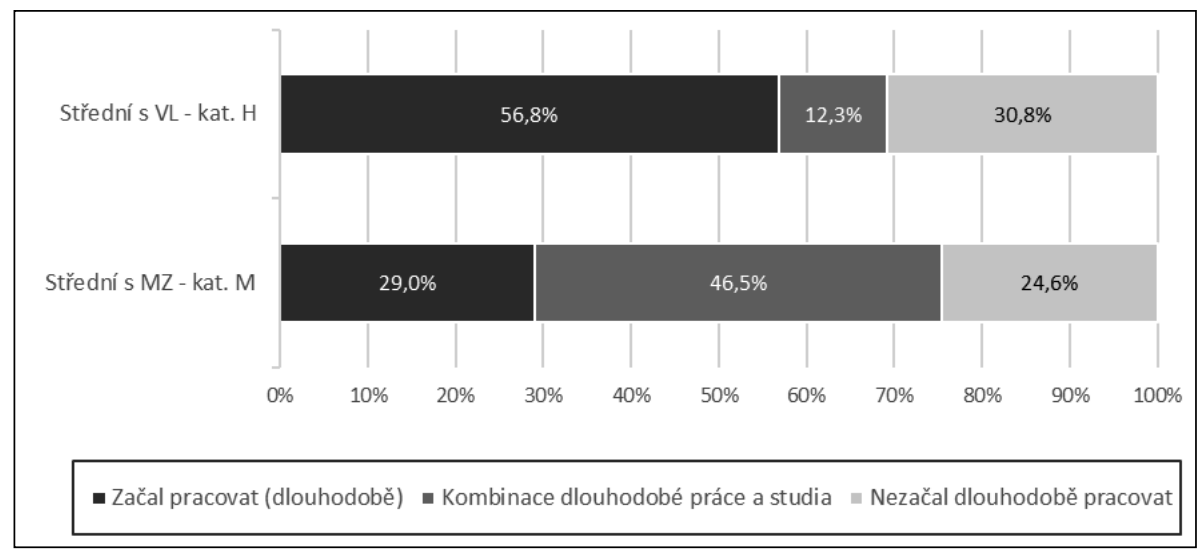

Obr. 3. Zahájení dlouhodobé pracovní aktivity a kombinace práce a studia ve sledovaném období 3 let od ukončení střední školy ( $\mathrm{v} \%$ odpovědí) 
$\mathrm{z}$ toho ovšem $46,5 \%$ kombinovalo různé formy pracovní aktivity se studiem a jen $24,6 \% \mathrm{z}$ nich nezahájilo dlouhodobou pracovní aktivitu.

Kombinace práce a studia zahrnuje široké spektrum možností. $Z$ absolventů maturitních oborů, kteří kombinovali studium VŠ nebo VOŠ s pracovní aktivitou, vykonávalo 34,3\% méně kvalifikovanou práci, zpravidla zároveň mimo obor, a 31,4\% kvalifikovanou práci, která souvisela s oborem absolvovaným na střední škole nebo studovaným na VŠ (34,3\%). Dále 21,6 \% uvedlo obecně, že kombinovali studium VŠ nebo VOŠ s kvalifikovanou prací, a asi $7,8 \%$ studovalo v terciárním vzdělávání a zároveň podnikalo formou OSVČ. Potvrzuje se tak trend, kdy se začátek pracovní dráhy přesouvá do období studia a již v rámci brigád a práce na částečný úvazek lze pozorovat určitý kariérní posun od méně kvalifikované práce $\mathrm{k}$ pozicím, které vyžadují odborné znalosti, často přímo ze studovaného oboru (Trhlíková, 2017). Toto „zaháčkování“ na trhu práce se promítá i do skutečnosti, že řada absolventů získává první stálé zaměstnání právě na základě kontaktů ze studijní praxe nebo brigád během studia ( $21 \%$ vyučených a $16 \%$ absolventů maturitních oborů).

Př́nosem kombinace studia a pracovních aktivit je určitý „synergický“ efekt a možnost vyzkoušet si teoretické poznatky vyučované ve škole prímo v praxi. Na druhé straně, pokud žáci začnou během studia na střední škole pracovat v jiném oboru, častěji pak volí jiný obor i v terciárním vzdělávání. Pracovní zku- šenost $\mathrm{v}$ jiném oboru uvedlo jako důvod zahájení VŠ v jiném oboru 18,8\% z nich.

\section{Pracovní uplatnění v oboru}

Jedním z důležitých aspektů úspěšného začlenění na trhu práce je uplatnění absolventů v oboru. $\mathrm{V}$ rámci šetření byl zjištován záměr absolventů pracovat v oboru, dále skutečnost po skončení střední školy a aktuální situace po třech letech (obr. 4).

$\mathrm{V}$ kategorii učebních oborů mělo v posledním ročníku střední školy zájem pracovat přímo v oboru $51,0 \% \mathrm{z}$ nich, dalších $11,0 \%$ zvažovalo práci v absolvovaném nebo př́íbuzném oboru. Ve skutečnosti se po vyučení přímo $\mathrm{v}$ oboru uplatnilo 54,4\% absolventů, 20,5\% pracovalo v prŕibuzném oboru a $25,0 \%$ si našlo práci mimo obor. Po třech letech od vyučení pak došlo k dalšímu odlivu z oboru, takže přímo v oboru zůstalo jen 36,0\% vyučených, $18,6 \%$ pracovalo v príbuzném oboru a $45,3 \%$ odešlo mimo obor.

$\mathrm{V}$ kategorii absolventů maturitních oborů (kategorie M) byl původní zájem pracovat v oboru mírně vyšší. $\mathrm{V}$ oboru se chtělo uplatnit $54,6 \%$ a $15,8 \%$ uvažovalo o zaměstnání ve svém nebo $\mathrm{v}$ príbuzném oboru. Po ukončení střední školy ovšem zahájilo pracovní dráhu prímo $\mathrm{v}$ oboru jen $42,1 \%$ absolventů maturitních oborů, v př́buzném oboru $26,7 \%$ a pracovat do jiného oboru odešlo $31,3 \%$ z nich. Podobně jako u vyučených, $s$ odstupem tří let od ukončení střední školy se procento pracujících ve svém oboru ještě snížilo, takže v oboru zůstalo jen $34,3 \%$, v př́ibuzném oboru $21,4 \%$ a $44,2 \%$ odešlo 


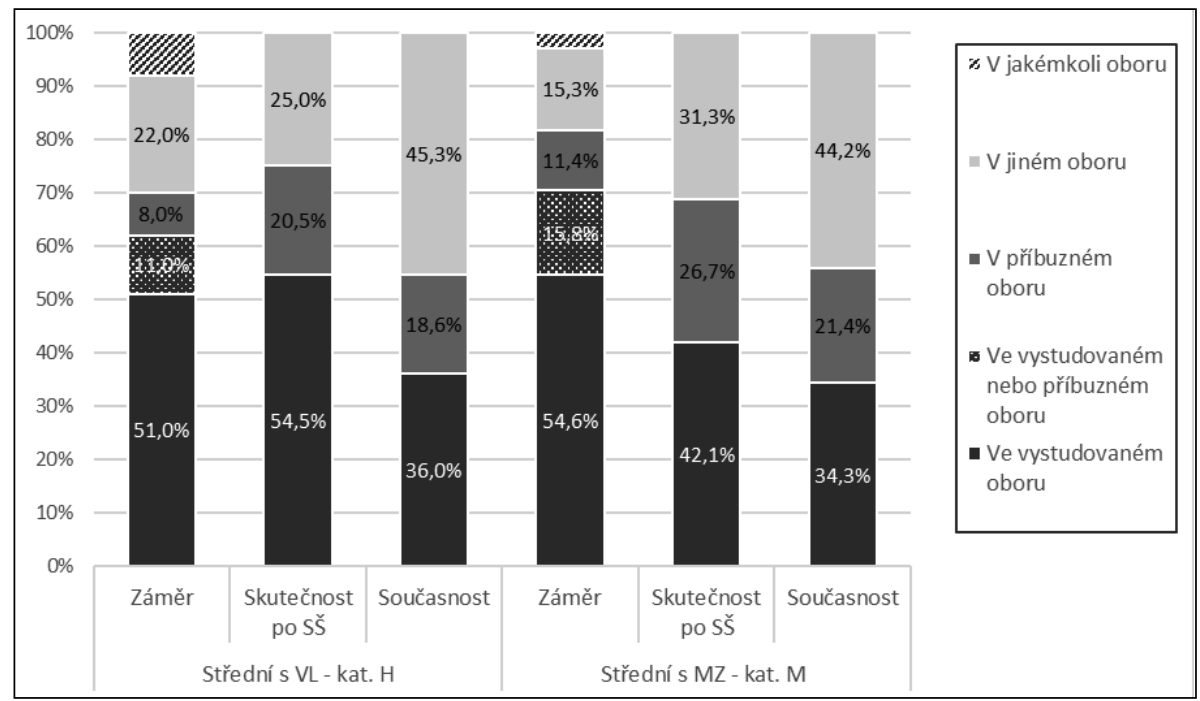

Obr. 4. Plánované a reálné uplatnění absolventů v oboru (v \% odpovědí) ${ }^{2}$

zcela mimo obor. Rozdíly mezi vyučenými a absolventy maturitních oborů $\mathrm{v}$ rámci sledovaného vzorku tak nejsou príliš výrazné.

Nejvýraznějším důvodem odchodu za prací do jiného oboru v obou kategoriích (obr. 5) byla lepší nebo zajímavější nabídka práce $\mathrm{v}$ jiném oboru $(64,4 \%$ a $64,6 \%$ z těch, kteří pracují mimo obor). $\mathrm{V}$ kategorii vyučených jsou pak tradičně více zastoupeny důvody související s charakterem a podmínkami práce a jejím oceněním. Nevyhovující pracovní podmínky jako důvod práce mimo obor uvádí 40,0\% vyučených oproti $29,2 \%$ absolventů maturitních oborů. Dalším častěji deklarovaným důvodem $\mathrm{v}$ kategorii vyučených je nízký plat (53,3\% oproti $35,9 \%$ ). Navzdory př́iznivé situaci na trhu práce jsou mezi důvody práce mimo obor uváděny u vyučených častěji i potíže se získáním práce v oboru (44,4\% oproti 39,6 \%).

Podstatným důvodem odchodu za prací mimo obor je nezájem o obor. Odpověd', že v oboru nikdy pracovat nechtěl/a, je opět častější u vyučených (37,8\% oproti $27,6 \%$ ), ztráta zájmu o obor je naopak v obou kategoriích na zhruba podobné úrovni $(37,8 \%$ a $40,6 \%)$. Přibližně pětina respondentů si našla práci v jiném oboru, protože původní obor nepovažují za perspektivní $(22,2 \%$ a $19,3 \%)$. Méně častým důvodem je dojíždění $(24,4 \%$ a $14,1 \%)$ nebo rodinné důvody $(22,2 \%$ a $10,4 \%)$.

${ }^{2}$ Otázka byla vztahována k oboru na střední škole. 


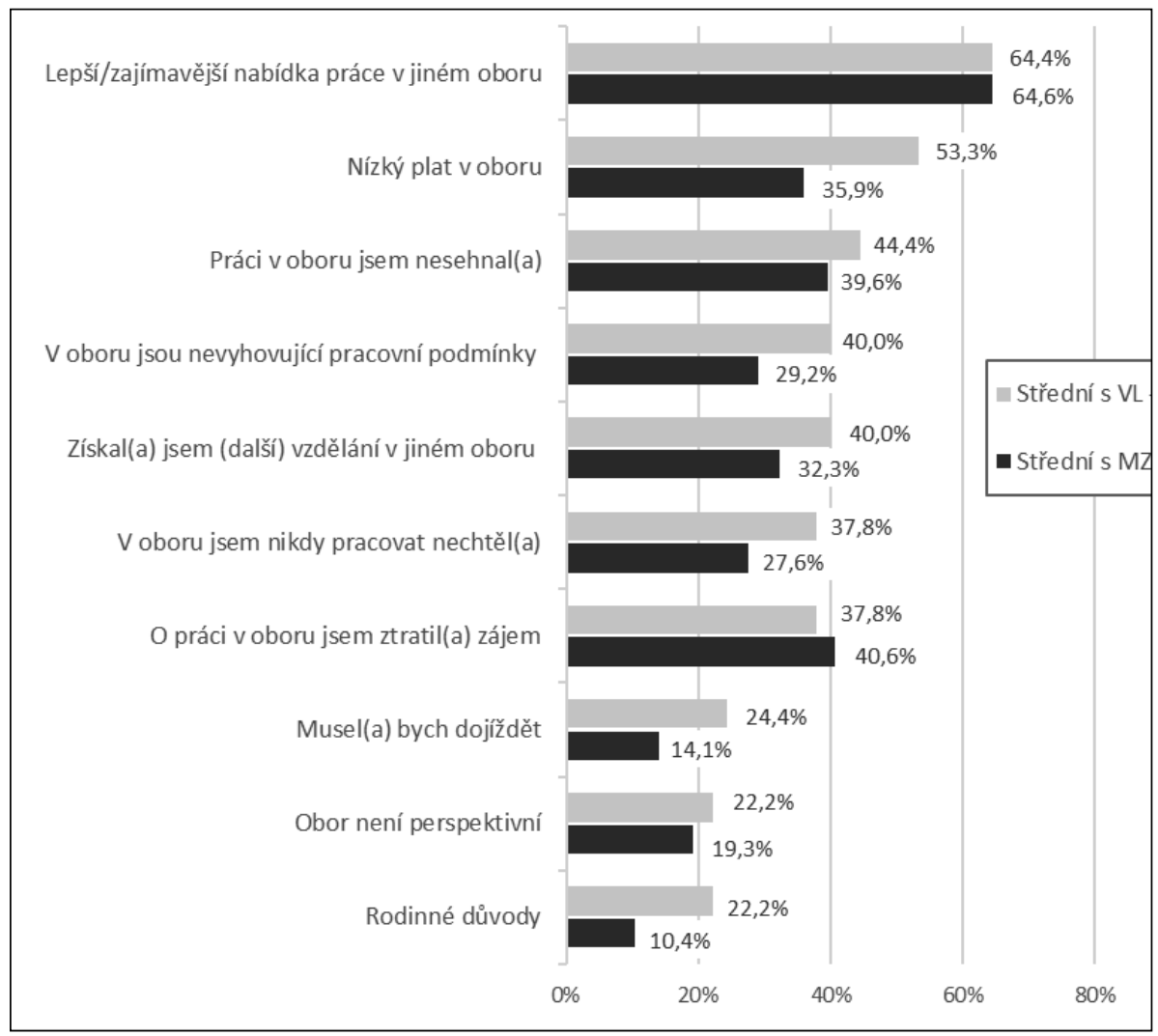

Obr. 5. Důvody odchodu za prací mimo obor (v \% odpovědí rozhodně ano + spíše ano, absolventi tři roky od ukončení SŠ, kteří pracují mimo obor; možnost výběru více odpovědí současně)

Oba důvody byly opět častěji zastoupeny v kategorii vyučených.

\section{Znalosti a dovednosti, které absol- ventům na trhu práce chybí}

Důležitým tématem šetření, jehož cílem je poskytnout zpětnou vazbu, je otázka, jaké dovednosti a znalosti absol- ventům při vstupu na trh práce chyběly. Z hlediska požadavků trhu práce absolventi nejčastěji uváděli, že jim chyběly praktické dovednosti v oboru. Tuto odpověd' uvedlo $52,5 \%$ absolventů maturitních oborů (kategorie $\mathrm{M}$ ), resp. 51,2\% z těch, kteří pokračovali v terciárním vzdělávání, dále 48,7\% vyučených, kteří zahájili nástavbové studium. V kategorii vyučených, 
kteří vstoupili na trh práce, byly chybějící praktické dovednosti uváděny $s$ nižší frekvencí $(38,5 \%$ ), ovšem i tak zaujímají první př́čku z hlediska kompetencí, které vyučení postrádali.

Na druhém místě v žebrríčku pak absolventi uváděli, že jim z pohledu požadavků na trhu práce chyběla vyšší úroveň vzdělání. Nejčastěji tuto odpověd' uváděli vyučení, kteří zahájili nástavbové studium (48,7 \%), méně často absolventi maturitních oborů $(44,0 \%)$ a s ještě nižší frekvencí ti, kteří zahájili terciární vzdělávání (37,7 \%).

Tradičně slabým místem školní přípravy je znalost cizího jazyka. S tímto nedostatkem se potýkali opět nejčastěji vyučení, kteří pokračovali v nástavbovém studiu (59,0\%). Nedostatečná znalost cizího jazyka nicméně byla limitujícím faktorem i pro více než třetinu absolventů maturitních oborů $(38,0 \%$, resp. $36,7 \%$ z těch, kteří pokračovali na VŠ nebo VOŠ). Lepší znalost cizího jazyka by z hlediska požadavků trhu práce potřebovalo i $30,8 \%$ vyučených.

$S$ nižší frekvencí si absolventi stěžovali i na nedostatek teoretických znalostí v oboru. Nejčastěji na tento problém naráželi opět vyučení, kteří pokračovali v nástavbovém studiu (41,0\%). Naopak absolventi pokračující na VŠ nebo VOŠ tento problém zpravidla neměli $(23,7 \%)$.

Určitou překážku představovala také absence manažerských dovedností a schopnost vést lidi. $S$ jejich nedostatkem se potýkali opět nejčastěji absolventi, kteří zahájili nástavbové studium (43,6\%). To zřejmě souvisí se skutečností, že nejfrekventovanějším oborem nástavbového studia je obor
Podnikání (v ostatních kategoriích uvádělo tento nedostatek $28,8-38,0 \%$ respondentů). Téměř třetina dotázaných mezi překážkami zmiňovala také nedostatek dalších „soft skills“, jako jsou schopnost prezentace a komunikační dovednosti (26-30\% dotázaných). $\mathrm{V}$ omezené míre představovaly problém také nedostatečně rozvíjené schopnosti týmové práce $(14,5-23,1 \%)$ a dovednosti pracovat s PC (13,5-22,0 \%).

\section{ZÁVĚR}

Úspěšnost absolventů škol a jejich plnohodnotné zapojení a uplatnění $\mathrm{v}$ oboru představuje důležitý indikátor a zpětnou vazbu pro vzdělávací systém a je využíváno jako důležitý datový zdroj např. i v oblasti kariérového poradenství. Rovněž poskytuje informace o „silných“ a „slabých“ stránkách školní přípravy, včetně podnětů pro úpravy obsahu vzdělávání.

Z výsledků šetření je patrné rozporuplné hodnocení absolvované vzdělávací dráhy, zejména v kategorii vyučených. Ti hodnotí celkovou úroveň školní přípravy poměrně pozitivně $(82,2 \%$ kladných hodnocení), na druhou stranu tradičně vyjadřují ve srovnání s absolventy maturitních oborů nižší spokojenost jak se zvoleným oborem, tak i s úrovní vzdělání. $\mathrm{Z}$ analýzy vyplývá, že pryíciny této nespokojenosti zřejmě $\mathrm{z}$ části spočívají $\mathrm{v}$ podmínkách trhu práce, zejména $\mathrm{v}$ horších pracovních podmínkách a $\mathrm{v}$ nižším platovém ohodnocení. Významné procento absolventů středních odborných škol tak odchází pracovat mimo obor, at už z důvodu lepší pracovní nabídky, nespokoje- 
nosti s platem nebo ztráty zájmu o obor. Toto zjištění na jednu stranu ukazuje potřebnou flexibilitu absolventů a jejich schopnost pružně reagovat na požadavky trhu práce, na straně druhé je zřejmé, že absolventi ve vztahu mezi vzdělávacím systémem a trhem práce nejsou jen pasivním objektem a že možnosti administrativní podpory a směrování žáků do konkrétních oborů jsou omezené.
Analýzy dále potvrdily, že i v ČR, podobně jako v jiných zemích EU, se prosazuje trend stále složitějšího a více rozvolněného přechodu ze vzdělávání na trh práce. $\mathrm{V}$ souvislosti s rychlými technologickými změnami a potřebou celoživotního vzdělávání tak lze zřejmě očekávat, že trend vzájemného prolínání a ovlivňování pracovního a studijního života bude i nadále pokračovat.

\section{Literatura}

Descy, P., \& Tessaring, M. (2002). Training and learning for competence. Second report on vocational training research in Europe: executive summary. Revised edition. Cedefop Reference series 31. Luxembourg: Office for Official Publications of the European Communities. Dostupné z www.cedefop.europa.eu

Descy, P., \& Tessaring, M. (2005). The value of learning. Evaluation and impact of education and training. Third report on vocational training research in Europe. Synthesis report. Cedefop Reference series 61. Luxembourg: Office for Official Publications of the European Communities. 2005. Dostupné z www.cedefop.europa.eu

Garonna, P., \& Ryan P. (1991). The regulation and deregulation of youth economic activity. In P. Ryan, P. Garonna, R. C. Edwards (Eds.), The problem of youth. London: Palgrave Macmillan. Dostupné z https://link.springer.com

Hannan, D., Raffe, D., \& Smyth, E. (1996). Cross-national research on school to work transitions: An analytic framework. Paris: OECD. Dostupné $\mathrm{z}$ https://search.oecd.org

Koucký, J., Ryška, R., \& Zelenka, M. (2014). Reflexe vzdèláni a uplatněni absolventů vysokých škol. Výsledky šetreni REFLEX 2013. Praha: Pedagogická fakulta UK.

OECD. (2000). From initial education to working life: Making transitions work. Paris: OECD.. Dostupné z https://books.google.cz

Ryan, P. (2001). The school-to-work transition: A cross-national perspective. Journal of Economic Literature, 39(1): 34-92.

Raffe, D. (2011). Cross-national differences in education-work transitions, pp. in M. London (Ed.), The Oxford handbook of lifelong learning (312-328). New York: Oxford University Press. Dostupné z https://webcache.googleusercontent.com

Trhlíková, J. (2013). Využití kvalifikace absolventů střednich škol na trhu práce. Zpráva ze šetřeni absolventů škol. Praha: NÚV.

Trhlíková, J. (2014). Prechod absolventů střednich škol na trh práce - srovnáni situace absolventů učebnich a maturitnich oborů. Praha: NÚV. 
Trhlíková, J. (2017). Přechod absolventů střednich škol na trh práce. Vzdèlávaci a profesni dráha absolventů SOŠ. Analýza rozhovorů. Praha: NÚV.

Úlovec, M., \& Vojtěch, J. (2018). Nezaměstnanost absolventů škol se střednim a vy̌ším odborným vzdělánim - 2018. Praha: NÚV.

Vojtěch, J., \& Kleňha, D. (2018). Přechod absolventů středních škol do terciárního vzdělávání - 2017/18. Praha: NÚV.

Vojtěch, J., \& Chamoutová, D. (2019). Vývoj vzdělanostní a oborové struktury žáků a studentů ve střednim a vy̌sšim odborném vzděláváni v $\check{C} R$ a v krajich $\check{C} R$ a postaveni mladých lidí na trhu práce ve srovnáni se stavem v Evropské unii 2018/19. Praha: NÚV.

Ing. Bc. Jana Trhliková

Národni uistav odborného vzdèláváni, Praha; e-mail: jana.trhlikova@nuv.cz

TRHLÍKOVÁ, J. Middle Vocational School-Leavers and their Transition to the Job Market

This paper deals with selected aspects of the transition of middle vocational school-leavers into the job market. It focuses on comparison of those who specialised in apprentice subjects and those who specialised in "maturita" (more theoretical, academic) subjects over a period of three years since they left school.

The goal of the paper is to present information about the results of a survey of middle vocational school-leavers conducted in 2018 on a sample around 1,000 respondents at the National Institute for Education as an important form of feedback on the transition of school-leavers into the job market.

Research methods: The research survey is conceived as a longitudinal quantitative questionnaire survey. The 2nd stage of the survey, which is the subject of this article, is focused on the level of success of transition into the job market and finding work in the field studied at school.

The results provide information about vocational school-leavers' critical reflection on educational and career path, and in particular make it possible to compare the relative level of satisfaction and employment of those who left school after studying apprenticeship disciplines and those who studied "maturita" (more general, academic) disciplines there.

The conclusions of the research survey make it possible to identify problems, needs and barriers in the framework of career choice, weak points in education from the point of view of school leavers, and level of readiness for the work market and tertiary education.

Keywords: middle vocational school-leavers, job market, finding work in field studied, transition to job market. 